\title{
OS ESTUDOS SOBRE ORIENTE MÉDIO E MUNDO MUÇULMANO NO BRASIL NOS ÚLTIMOS 15 ANOS (2001 - 2016).
}

\author{
Peter Robert Demant
}

Para este novo número, Malala solicitou contribuições de pesquisadores brasileiros no lugar da costumeira chamada internacional por tema. 0 resultado tem sido quantitativamente mais farto do que o esperado - tanto que já decidimos abrir também as colunas do próximo número para aqueles textos aprovados que na presente edição não obtiveram espaço. A alta qualidade de muitos textos foi gratificante e apresentamos aqui alguns deles.A primeira observação que se impõe é a de um significativo crescimento do interesse acadêmico no país pelos estudos do Oriente Médio e do mundo muçulmano. 0 Brasil não está alheio à emergência de temas islâmicos nos debates públicos ao redor do mundo. Pensemos, por exemplo, na presença não mais negável das diásporas muçulmanas no ocidente, na recente e perigosa internacionalização de conflitos étnicos e religiosos no Mashriq (Oriente árabe) e em seus prolongamentos: as ondas de refugiados de guerra civil, fome e perseguição, e a proliferação do terrorismo jihadista. 0 Oriente Médio está batendo na porta do Brasil. Novamente - não pela primeira vez, mas desta vez talvez de maneira mais insistente. Por lamentáveis que sejam suas causas longínquas, os reflexos da campainha desse despertador médio-oriental na extensão do escopo acadêmico brasileiro, até agora fortemente ocupado com problemáticas tipicamente nacionais (ou, no máximo, latino-americanas), possuem elementos positivos.

Malala 7 abre com a entrevista com um acadêmico que tanto na sua biografia quanto em sua atuação profissional e científica exemplifica o laço entre o Brasil e o mundo árabe. Nizar Messari traz uma série de ponderações sobre o teor do interesse brasileiro no Oriente Médio, que ainda se pauta demais pela percepção do islã como ameaça: temos estudos sobre o mundo muçulmano mas não temos uma escola brasileira de tais estudos...

Nas seguintes paginas, Bouzid Izzerougene propõe uma comprida e sólida análise sobre o islamismo radical, introduzindo autores e fontes históricas ainda pouco conhecidos aqui, além de apresentar suas próprias ideias. Diogo Bercito desvenda a estrutura do Estado Islâmico com base em seus documentos internos e expõe seu caráter moderno. Enquanto estes artigos focalizam o político, outros apresentam facetas do islã ainda menos abordadas. É o caso de Emily Fonseca, que problematiza o conceito da história na época árabe clássica através da obra do historiador sírio medieval Ibn al-Athir. Malala tenta navegar um percurso que evita tanto a Scylla, da abordagem hiper-especialista e demasiadamente acadêmica, quanto o Charybdis, que sacrifica a profundeza a favor da facilidade. Buscamos oferecer artigos inéditos e originais, mas de agradável leitura ao 


\section{apresentação}

público educado lusófono, além de propor contribuições interessantes para leitores de fora (um dos artigos de pesquisador brasileiro está em inglês). Muitos dos textos que seguem são extratos de teses de mestrado ou doutorado que, achamos, respondem a essas exigências. Como tradicional em edições anteriores, o presente número também conta com o relato de campo do fotógrafo Thiago Caetano, cujo trabalho ilustra nossa capa, sobre refugiados muçulmanos em Berlim; com a resenha do livro 'O Caso Meursault', de Kamel Daoud, por Roberto da Rocha Rodrigues; e com a resenha do filme libanês 'Tramontane' de Vatche Boulghourjian, por Natalia Nahas Calfat.

Além dos acima-citados, não menos de dois artigos mais um ensaio atacam de ângulos variados o perene conflito israelo-árabe. Luiz Salgado Neto disseca as atitudes dos notáveis palestinos na era do Mandato britânico, chegando a tornar mais entendível (senão desculpável) a posição deste estrato preso entre o martelo da imigração judaica e a bigorna da politica colonial britânica. Mais polemicamente, Guilherme Morgenzstern Russo tenta elaborar analogias entre o sionismo e o apartheid na África do Sul. E Magno Paganelli oferece lições de espiritualidade tiradas das lutas pela independência da Índia e pela igualdade racial na África do Sul, que teriam aplicabilidade na Terra Prometida (prometida, muitas vezes, e a beneficiários contrastantes...).

Em termos de seu interesse intrínseco, esta concentração de atenção no quesito Israel-Palestina não é totalmente justificada. Para comparar, os múltiplos conflitos na Argélia, entre população autóctone muçulmana e pieds-noirs franceses, entre árabes e berberes, e entre islamistas radicais e secularistas nacionalistas ou socialistas proporcionam um "laboratório de coexistência" difícil e não menos instigante. 0 mesmo vale para os curdos, para o Líbano e para a Malásia. A Arábia Saudita ou a Turquia, duas outras panelas de pressão regionais à beira de explosão, representam cada uma interesses econômicos muitas vezes maiores, mesmo se (cenário improvável) israelenses e palestinos juntassem suas forças. Quanto ao Irã, ele combina uma originalidade política e teológica com um papel geopolítico não menos sensível do que o dos parceiros da contenda israelo-palestina. Mesmo assim, nenhum destes assuntos tem se beneficiado até agora no Malala (nem em outras publicações acadêmicas brasileiras) de muitas análises equivalentes àquelas dedicadas a Israel-Palestina. 0 enfoque em Israel-Palestina, que nós apenas seguimos, reflete uma supervalorização não apenas na academia nacional, mas em todo o mundo ocidental, e não apenas entre intelectuais como também na política. Muito já se tem escrito sobre as causas desta quase obsessão sem satisfatoriamente elucidá-la - seria um tema para futuros autores de nossa revista. Apenas ousaria aqui sugerir que "a questão judaica" da qual Israel é uma expressão direta está no DNA do universo (pós) cristão de maneira bem mais enraizada do que a equivalente (pace Edward Said) "questão oriental”, "árabe" ou "islâmica". 
Todos os textos que o leitor encontra abaixo são fruto de um processo de editoração meticulosa. E como nos números anteriores, nem todos os manuscritos foram aceitos. Um desafio recorrente é a politização excessiva de muitas produções. Na maioria dos casos, o choque se faz entre as demandas de uma objetividade mínima e o engajamento, por exemplo, marxista ou pós-moderno do autor. 0 problema não é coincidência nem específico ao campo dos estudos do Oriente Médio e do mundo muçulmano - embora ali a pressão por posicionamentos transcendendo o acadêmico seja particularmente urgente: a região que no passado deu ao mundo o judaísmo, o cristianismo e o islã, é também o berço de uma multidão de ideologias mais recentes, entre as quais pan-arabismo, a wataniyya com sua gama de nacionalismos, sionismo e antissionismo, wahabismo, e um universo de islamismos inclusive salafis e jihadis. Ainda, é natural que nossa revista, como o GT em geral, reflita antes de mais nada o choque das ideologias que conturba o Brasil de hoje.

Seria, portanto, talvez útil explicitar mais uma vez sucintamente nossa posição. Malala não é comprometida com nenhuma escola teórica ou tendência política. A maioria da comissão editorial do Grupo de Trabalho sobre Oriente Médio e Mundo Muçulmano se reconheceria provavelmente numa identificação com um ideal de emancipação e de valores humanos. Assim como a própria Malala Yousafzai, nos consideramos idealistas, mas o ideal é vago e sem dúvida bastante diferente para cada um(a). Malala não afasta de antemão da revista textos que tomam partido, não busca o sensacional e nem evita o polêmico, mas não estará sob o jugo de nenhuma ideologia ou religião. Não veiculará propagandas extremistas, mas idealmente oferece um espaço de aprendizado e debate para posições várias e até contraditórias. Um amplo leque de opiniões continuará sendo bem-vindo no boletim, desde que argumentado e não posto como a priori. Esperamos caminhar adiante com mais números cheios de informação e de ideias que provocam e estimulam.

Boa leitura!

Peter Demant Editor-Chefe da Revista Malala São Paulo, 03 de Abril de 2017. 